US Army Corps

of Engineers

Waterways Experiment

Station

\title{
Selecting Wave Gauge Sites for Monitoring Harbor Oscillations: A Case Study for Kahului Harbor, Hawaii
}

by Michele Okihiro, R. T. Guza, W. C. O'Reilly Scripps Institution of Oceanography

David D. McGehee

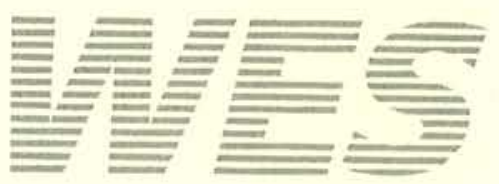

Approved For Public Release; Distribution Is Unlimited 
The contents of this report are not to be used for advertising, publication, or promotional purposes. Citation of trade names does not constitute an official endorsement or approval of the use of such commercial products. 


\section{Selecting Wave Gauge Sites for Monitoring Harbor Oscillations: A Case Study for Kahului Harbor, Hawaii}

by Michele Okihiro, R. T. Guza, W. C. O'Reilly

Scripps Institution of Oceanography

University of California, San Diego

La Jolla, CA

David D. McGehee

U.S. Army Corps of Engineers

Waterways Experiment Station

3909 Halls Ferry Road

Vicksburg, MS 39180-6199

Final report

Approved for public release; distribution is unlimited

Prepared for U.S. Army Corps of Engineers

Washington, DC 20314-1000

and State of Hawaii

Hawaii Department of Transportation, Harbors Division

79 S. Nimitz Hwy, Honolulu, HI 96813 


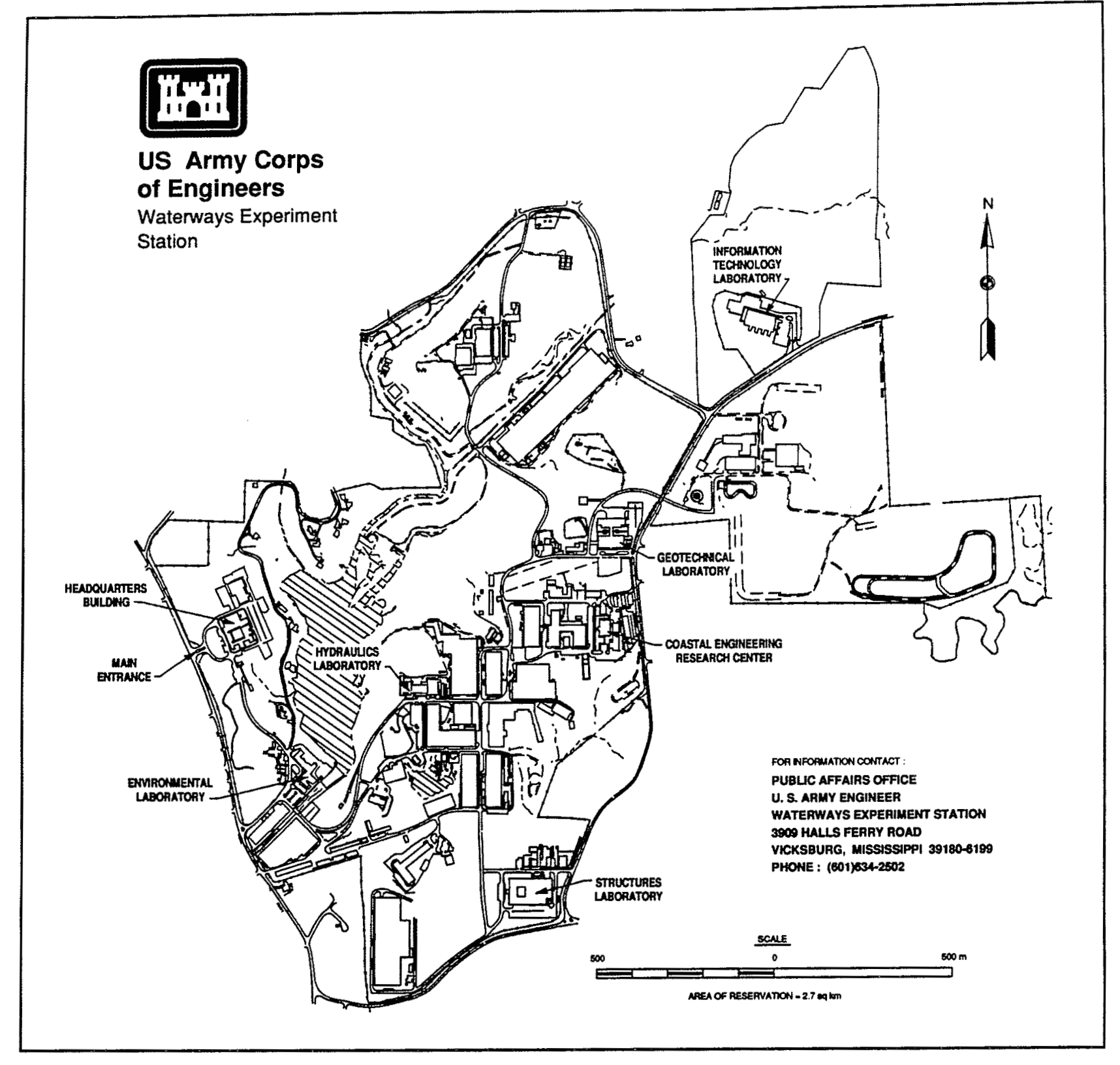

\section{Waterways Experiment Station Cataloging-in-Publication Data}

Selecting wave gauge sites for monitoring harbor oscillations : A case study for Kahului Harbor, Hawaii / by Michele Okihiro ... [et al.] ; prepared for U.S. Army Corps of Engineers and State of Hawaii, Hawaii Department of Transportation, Harbors Division ; monitored by U.S. Army Engineer Waterways Experiment Station.

33 p. : ill. ; $28 \mathrm{~cm}$. - (Miscellaneous paper ; CERC-94-10) Includes bibliographic references.

1. Harbors - Hawaii - Hydrodynamics. 2. Oceanography - Hawail Kahului Harbor. 3. Ocean waves - Hawaii - Measurement - Instruments. I. Okihiro, Michele. II. United States. Army. Corps of Engineers. III. U.S. Army Engineer Waterways Experiment Station. IV. Coastal Engineering Research Center (U.S.) V. Hawaii. Harbors Division. VI. Title: A case study for Kahului Harbor, Hawaii. VII. Series: Miscellaneous paper (U.S. Army Engineer Waterways Experiment Station) ; CERC-94-10.

TA7 W34m no.CERC-94-10 


\section{Contents}

Preface $\ldots \ldots \ldots \ldots \ldots \ldots \ldots \ldots$

1 -Introduction .................... 1

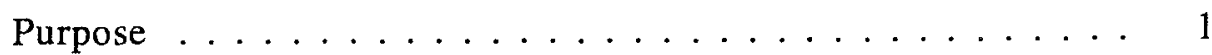

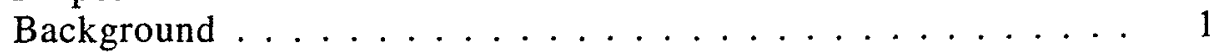

Kahului Harbor Site Description . . . . . . . . . . . . 2

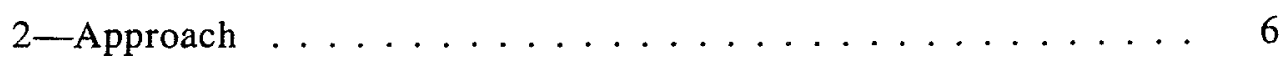

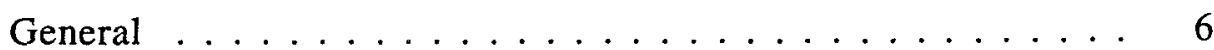

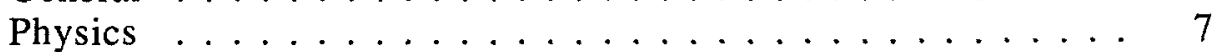

Logistics ............................. 9

3 -HARBD Numerical Model . . . . . . . . . . . . . . 11

HARBD Model Description . . . . . . . . . . . . . . . . 11

Finite Element Grids . . . . . . . . . . . . . . . . 12

4-HARBD Model Tests and Results . . . . . . . . . . . 13

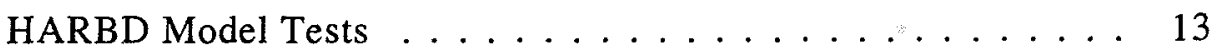

Inviscid Tests . . . . . . . . . . . . . . . . . 14

Constant Depth Harbor . . . . . . . . . . . . . . . . 15

Bottom Friction . . . . . . . . . . . . . . . . 16

Boundary Reflection . . . . . . . . . . . . . . . . . 17

Rubble-Mound Breakwaters . . . . . . . . . . . . 17

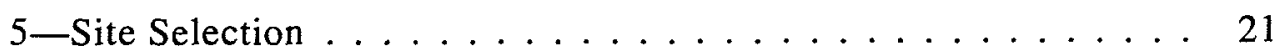

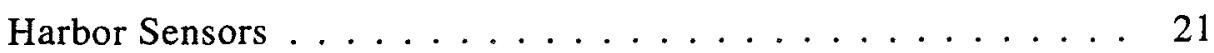

Offshore Array Site . . . . . . . . . . . . . . . . 21

Optional Autonomous Sensor Site . . . . . . . . . . . . . 24

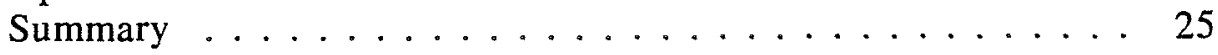

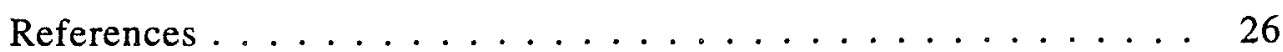

SF 298 


\section{List of Figures}

Figure 1. Kahului Harbor Site, Maui, Hawaii . . . . . . . . . 3

Figure 2. Offshore and harbor bathymetry at Kahului, Maui . . . . 4

Figure 3. Harbor bathymetry and sensor locations .......5

Figure 4. Progression of numerical models proposed . . . . . . . 8

Figure $5 . \quad$ HRBD model $\ldots \ldots \ldots \ldots$

Figure 6. Contours of model-predicted wave amplification . . . 16

Figure 7. Contours of wave amplification for $\mathrm{f}=0.0029 \mathrm{~Hz} \quad \ldots \quad 17$

Figure 8. Contours of wave amplification for $\mathrm{f}=0.0065 \mathrm{~Hz} \quad \ldots 18$

Figure 9. Contours of wave amplification for $\mathrm{f}=0.0077 \mathrm{~Hz} \quad \ldots 19$

Figure 10. Model-predicted amplification spectra ....... 20

Figure 11. Amplification spectra ............. 22

Figure 12. Refraction-diffraction model-predicted swell . . . . 23 


\section{Preface}

This report is published by the U.S. Army Engineer Waterways Experiment Station (WES) Coastal Engineering Research Center (CERC). The work was funded by the Field Wave Gaging Program (FWGP), a work unit of the U.S. Army Corps of Engineers Coastal Field Data Collection Program (CFDCP)and the Harbors Division of the State of Hawaii Department of Transportation (HDOT). At Headquarters, U.S. Army Corps of Engineers Technical Monitors for the CFDCP are Messrs. John G. Housley, John H. Lockhart, and Barry W. Holliday. The Program Manager of the CFDCP is Ms. Carolyn Holmes, CERC; the Principal Investigator of the FWGP is Mr. David McGehee, CERC. At HDOT, Mr. Robert Nagao is Head of the Planning Office, and Mr. Calvin Tsuda is Deputy Director for Harbors Division.

Mr. McGehee was under the supervision of Mr. William L. Preslan, Chief, Prototype Measurement and Analysis Branch, and Mr. Thomas W. Richardson, Chief, Engineering Development Division (CERC). Dr. James R. Houston was Director of CERC and Mr. Charles C. Calhoun, Jr., was Assistant Director of CERC.

Dr. Robert Guza was supported by the Office of Naval Research, which also provided access to a CRAY Y-MP computer for numerical modeling. HARBD model grids were created using the gridding software packages TRIGRID (Fisheries and Oceans, Canada) and MENTAT (MARC Analysis Research Corporation).

This report is the third in a series funded by the FWGP describing the methods used to select sites for wave gauges. The particular application is for the Kahului Harbor Study, a reimbursable work unit funded by the State of Hawaii Department of Transportation.

At the time of publication of this report, Dr. Robert W. Whalin was Director of WES and COL Bruce K. Howard, EN, was Commander. 


\section{Introduction}

\section{Purpose}

Wave measurements are required to observe and ultimately predict the response of the ocean to dynamic loading. While remote sensing techniques may eventually provide continuous spatial definition of wave energy for large regions, current engineering practice relies on point measurements from wave gauges. The U.S. Army Corps of Engineers' Field Wave Gaging Program (FWGP) operates a nationwide network of wave gauges and serves as the Corps' central access point for all U.S. wave data. The program also supports a variety of activities to enhance the quality and efficiency of wave data collection, processing, and distribution. This is the third in a series of FWGP reports describing, through case studies, the process of selecting sites for wave gauges.

The selection of sites for measuring wave energy in a particular environment is often a heuristic exercise wherein engineering judgement is used to balance the sometimes conflicting requirements of defining the processes (physics), ensuring data capture (logistics), and managing resources (economics). Balancing these aspects may never yield to purely analytic solution, but tools can be developed to quantify benefits and costs. In O'Reilly and McGehee (in preparation) a technique borrowed from metallurgy-simulated annealing is described that optimizes the information content of a network within a region (assumed to have uniform incident conditions at its outer boundary). Basco and McGehee (1990) walk through all the steps involved in selecting the exact gauge location once a general site has been identified. This paper illustrates use of two different wave transformation models to optimize gauge sites in a local gauge network for a harbor oscillation study. The harbor under consideration is Kahului Harbor, Hawaii.

\section{Background}

As with the other Hawaiian Islands, Maui is almost totally dependent on ocean transportation for its basic supplies, and Kahului Harbor is the 
only commercial deep-draft harbor on this island. In order to handle the growing cargo tonnage generated by the growth in population and expanding economy, and to keep pace with the technological and operational changes occurring in the maritime industry, modifications to the present port facilities are being planned (Hawaii Department of Transportation (HDOT) 1989). HDOT requested that the U.S. Army Engineer Waterways Experiment Station Coastal Engineering Research Center (CERC) conduct a study of the existing conditions at Kahului Harbor and make recommendations to maximize the use of available areas for harbor expansion and navigational improvements.

Although existing swell conditions at Kahului Harbor have not resulted in complete closure of the harbor, they have hampered the efficient use of some berths. Though unlikely, there is concern that supply lines to the island might be cut off if the entrance channel were temporarily blocked (HDOT 1989). It is not clear whether the existing problems are due to swell entering the harbor or lower frequency 'seiche' motions, though significant swell can be observed throughout the harbor when northerly storms occur. Operational problems in many harbors are due to seiche (also called surge or resonance) which is characterized by a concentration of energy in standing wave modes at the resonant frequencies, typically between 0.001 and $0.01 \mathrm{~Hz}$ for small harbors. Energy at these frequencies is amplified within the harbor, relative to outside the harbor, whereas harbor motions at other frequencies are suppressed. In harbors the size of Kahului, the lowest frequency resonances may be driven by atmospherically excited internal and shelf waves, whereas higher frequency modes are usually driven by nonlinear interactions between swell and sea. The forcing and damping of resonant modes may differ from harbor to harbor depending on the harbor geometry, surface wave climatology and general oceanographic properties, (i.e., stratification and wind field) in the surrounding offshore area. It is not presently possible to quantitatively predict the magnitude of harbor seiches either numerically or with physical models, owing to the complexity of the seiche excitation and damping processes. In situ observations are essential to the characterization of harbor seiche and to provide the unknown values of parameters necessary for modeling studies.

\section{Kahului Harbor Site Description}

Kahului Harbor is situated at the apex of a large V-shaped bay formed by an indentation on the north shore of the island (Figure 1). Offshore bathymetry at this site is complicated (Figure 2). East of the harbor the bathymetry is characterized by shallow areas $(<3 \mathrm{~m})$ which extend nearly 1-2 km offshore whereas to the west the bottom slope is steeper and relatively constant. Directly offshore of the entrance channel the depth is about $10 \mathrm{~m}$. 


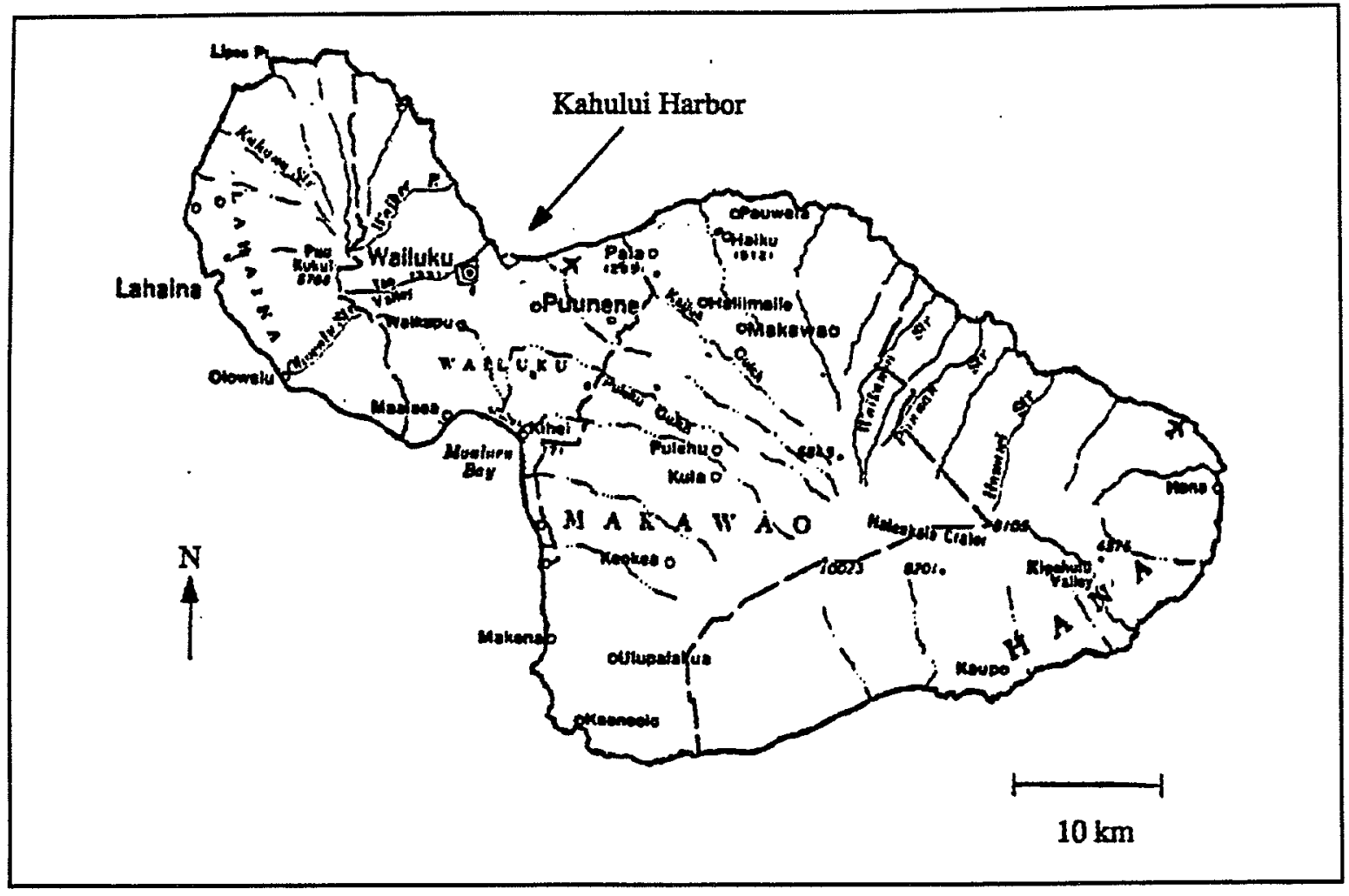

Figure 1. Kahului Harbor Site, Maui, Hawaii

Overall harbor dimensions are approximately $1 \mathrm{~km}$ by $1 \mathrm{~km}$, although depths along the unused western and southern perimeter are only a few meters (Figure 3). The present operational harbor basin defined by the 10 to $11-\mathrm{m}$ depth contour (Figure 3 ) is approximately $730 \mathrm{~m}$ long and $600 \mathrm{~m}$ wide. The $-200-\mathrm{m}$-wide entrance channel faces northward and is bounded by two rubble-mound breakwaters. Although under most wave conditions these breakwaters successfully protect the harbor, energetic northerly swell reaches all piers and sometimes interferes with harbor operations (HDOT 1989). 


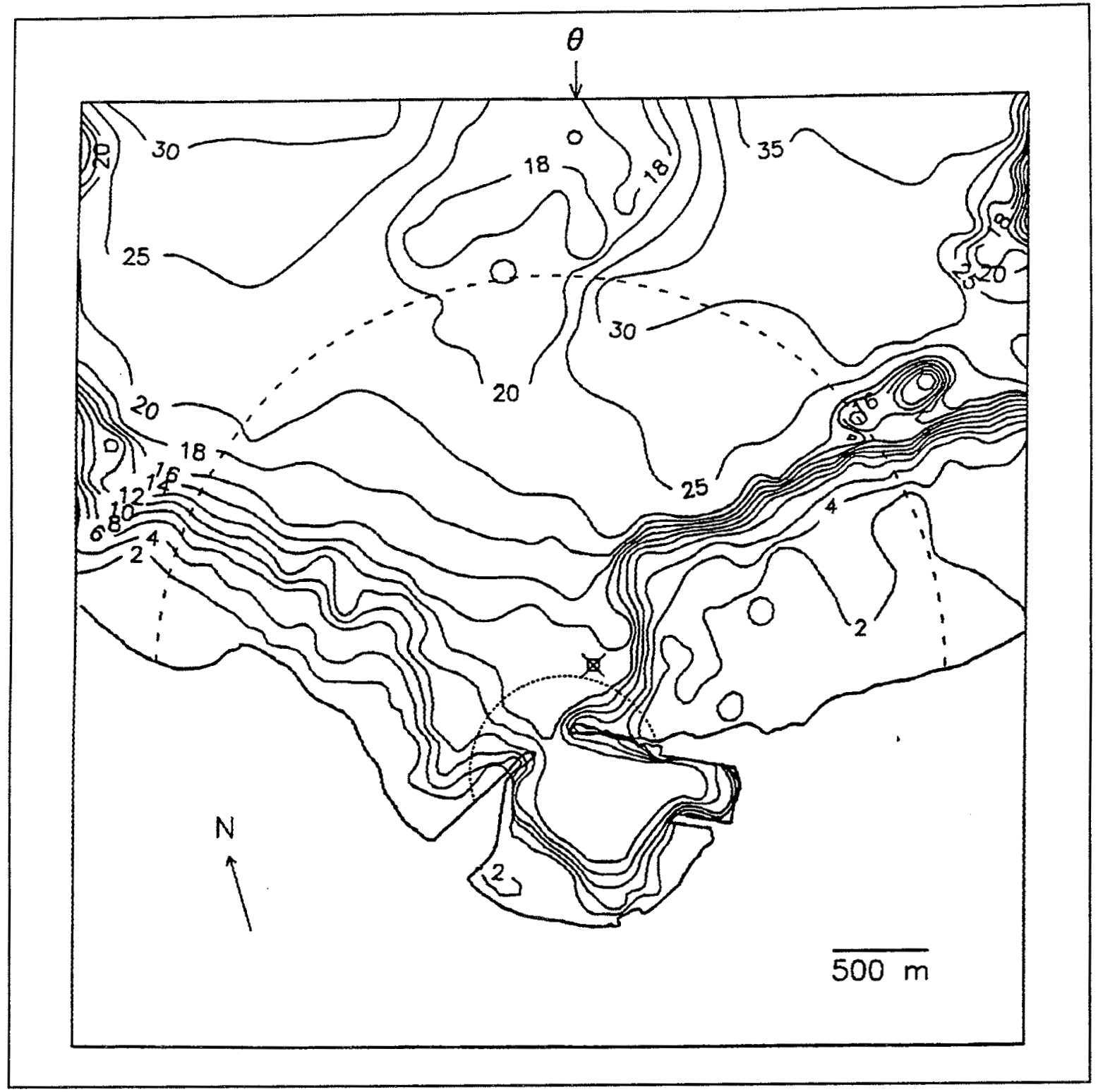

Figure 2. Offshore and harbor bathymetry at Kahului, Maui. Dashed line indicates the near-field HARBD numerical model grid boundary for Test 1 and the dotted line is the boundary for all other tests. $\theta$ (top of figure) is the incident wave direction. The site selected for the offshore slope array is shown by a crossed square 


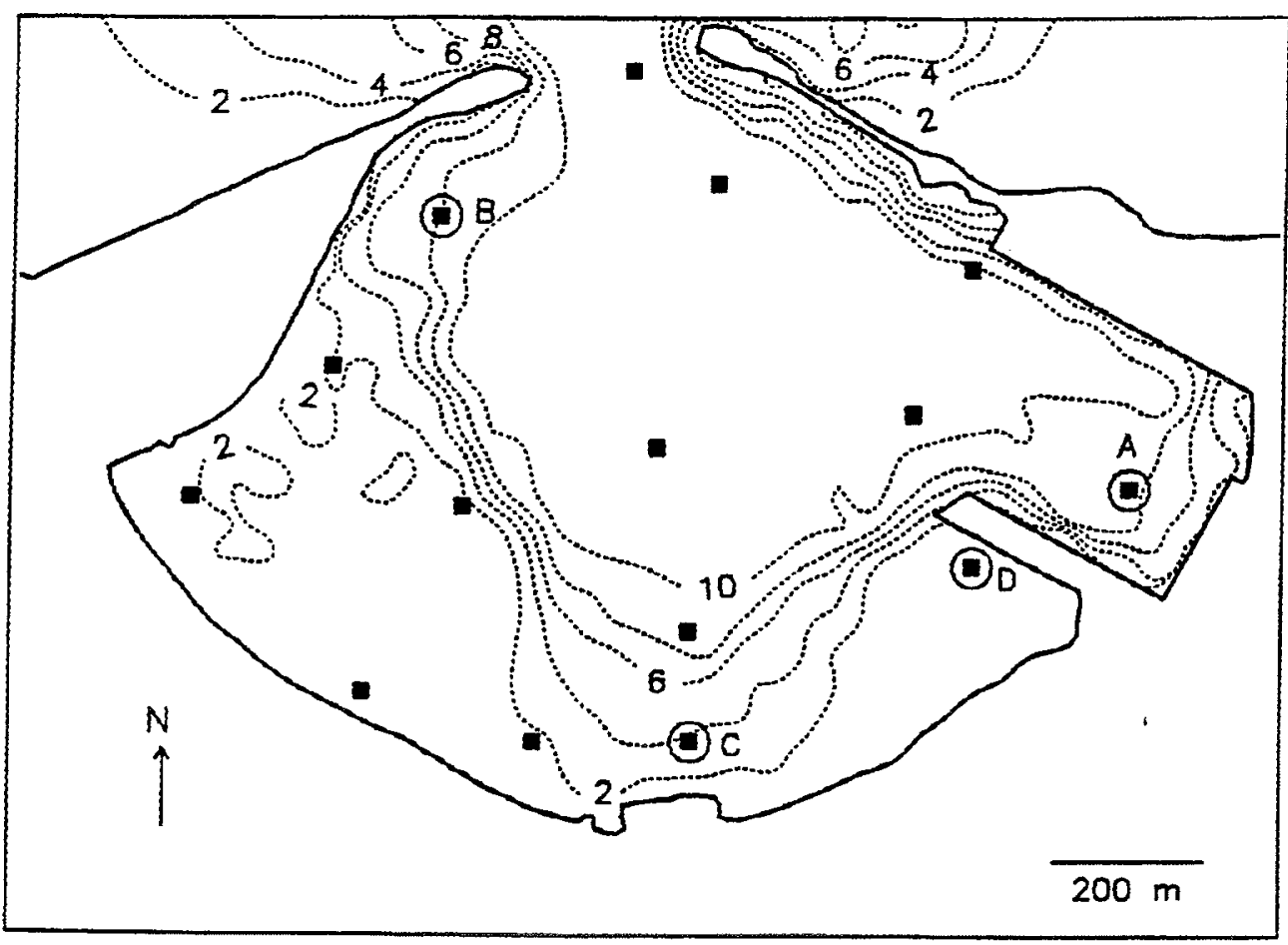

Figure 3. Harbor bathymetry and sensor locations. The solid symbols indicate positions for which HARBD model results are shown in subsequent figures and the lettered circles are the harbor sites selected for field data collection 


\section{Approach}

\section{General}

The gauging plan arrived at in this report is one element of a broader investigation planned for Kahului Harbor.

CERC has proposed a comprehensive study to address the effect of various modifications to the harbor on amplitude and incidence of occurrence of both swell and harbor seiche throughout the harbor. The approach is to utilize a three-dimensional physical model and a numerical harbor oscillation model (the HARBD model) to simulate the response of the existing harbor to gravity and infragravity energy. These models will be calibrated and verified with field measurements. A directional array placed outside the harbor will measure incident waves that excite the harbor. Four nondirectional gauges placed throughout the harbor will measure the response of the harbor. Once the models have been validated, alternative plans will be compared.

Two additional models will be utilized to define the statistical wave climate outside the harbor so that the probability of occurrence of different forcing conditions can be estimated. The first is WISWAVE, the model used by the CERC Wave Information Study (WIS) (Corson et al. 1986) - a hindcast of deep-ocean wave conditions at discrete stations based on longterm meteorological observations. Completed for the 20-year interval from 1956-1975, the WIS hindcast is scheduled in 1996 for updating through 1995, which will cover the period when the Kahului Harbor gauges are operating. The updated hindcast will be validated against a directional wave gauge located approximately 40 miles northwest of Maui. This gauge was deployed in January 1993 by the National Data Buoy Center and was funded by the FWGP as part of a joint effort between the Corps and the State of Hawaii to define the wave climate for the islands.

The final model required is a site-specific wave transformation model that will predict wave conditions outside the harbor using the validated WIS hindcast as input. Due to the complex bathymetry approaching the harbor, this model will incorporate both refraction and diffraction effects. The wave transformation model's output will be validated through 
comparisons with the directional array used for input to the harbor oscillation model. Figure 4 illustrates, and Table 1 summarizes, the progression of models to be used to provide the statistical predications of the harbor response.

To design the Kahului gauge network, two numerical models were run in advance of the gauge placement to indicate the optimum locations for the gauges - the HARBD harbor oscillation model (Chen 1986) and the refraction/diffraction (R/D) wave transformation model developed at the Scripps Institution of Oceanography (SIO) (O'Reilly and Guza 1993). Output from the models was examined to support or reject sites selected through the more traditional "inspection" approach.

While quantitative results from the uncalibrated numerical models are not always reliable, valuable qualitative information can be derived by running the models prior to obtaining the measurements. The objectives were to predict: (a) probable modes of harbor oscillation; (b) sensitivity of the harbor system to variations in geometry and bathymetry; and (c) locations outside the harbor that are strongly influenced by local bathymetry, i.e., where conditions would be unrepresentative of the incident conditions for the harbor models.

The principal concern expressed by the HDOT, and thus the emphasis for the gauge selection process, was the potential response of commercial vessels to harbor oscillations while moored at their berths. Thus, while HARBD is capable of modeling infragravity and gravity waves, it was run here to identify the harbor seiche modes. It is proposed to also be calibrated for swell during the comprehensive study. The R/D model was run at a single representative gravity $(0.058 \mathrm{~Hz}$, or $17 \mathrm{sec})$ wave approaching from two directions to investigate the variability of swell conditions outside the harbor.

\section{Physics}

In order to run the models in advance, the best available information on bathymetry inside and outside the harbor was utilized. Additional experience with the models, and examination of the measurements, will help determine if additional or more updated bathymetric data are required. Other assumptions were made about the reflectivity of harbor boundaries and the configuration of fill underneath piers that will have to be verified.

While all of the numerical models above are spectral, they are linear in frequency; i.e., they can only predict changes in energy or direction within each single frequency band of the spectrum. Observations in nature indicate that nonlinear energy transformation from gravity waves to infragravity waves is responsible for excitation of harbor seiche during storm conditions. The proposed physical model has the potential to duplicate this process, though questions remain on the scale effects. As part of 
$\infty$

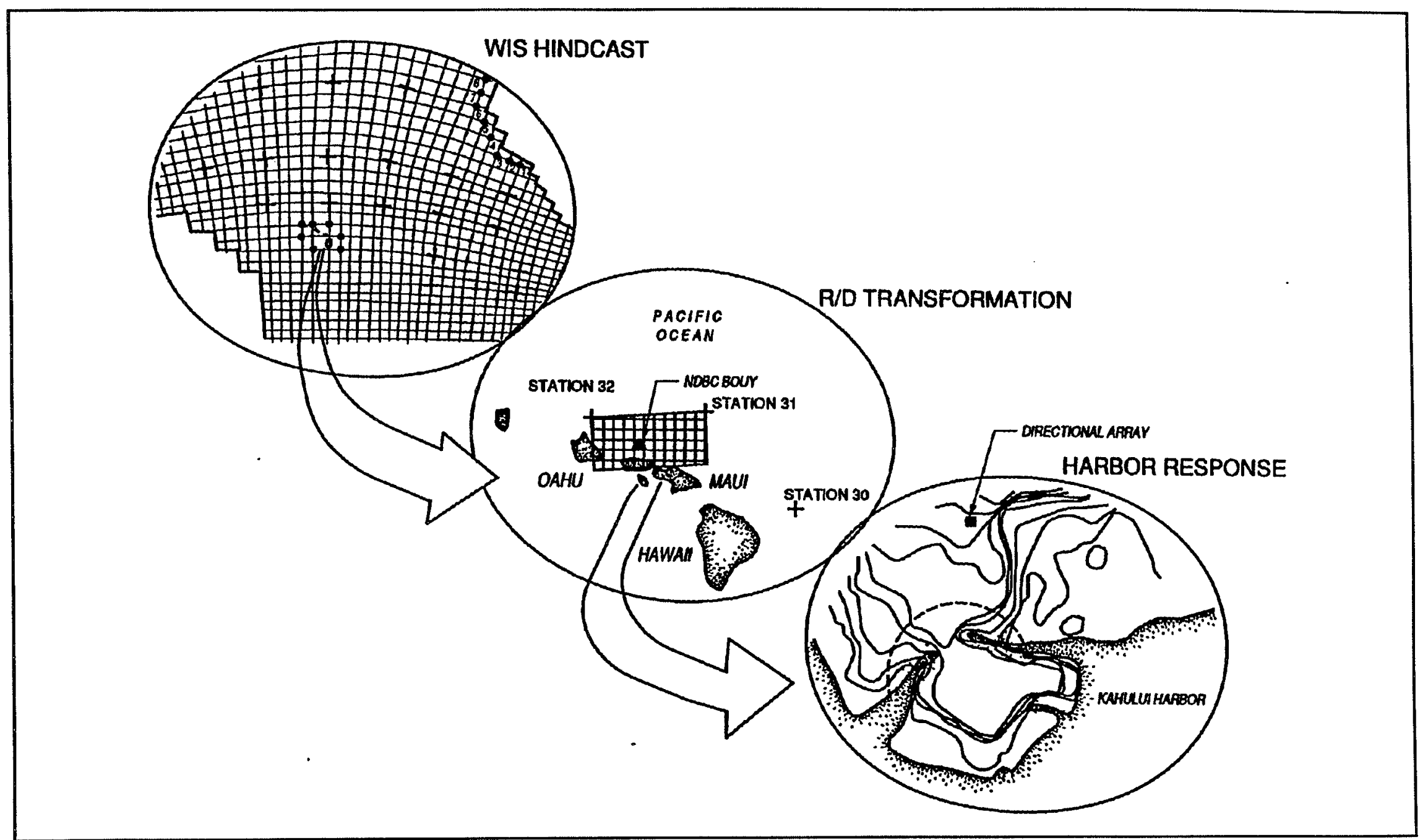

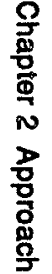

Figure 4. Progression of numerical models proposed. Full ocean scale WIS hindcast output drives wave transformation model. Output of wave transformation model is input for HARBD and 3-D physical models 
Table 1

Summary of Models

\begin{tabular}{|l|l|l|l|l|l|}
\hline Model & Scale & Grid & Input & Output & Validate \\
\hline $\begin{array}{l}\text { WIS numerical } \\
\text { wave generated } \\
\text { model }\end{array}$ & North Pacific & $0100 \mathrm{~km}^{1}$ & $\begin{array}{l}\text { Atmospheric } \\
\text { pressure, 20+ } \\
\text { years }\end{array}$ & $\begin{array}{l}\text { 2-D spectra@ } \\
\text { Phase I stations }\end{array}$ & NDBC buoys \\
\hline $\begin{array}{l}\text { R/D numerical } \\
\text { wave } \\
\text { transformation } \\
\text { model }\end{array}$ & $\begin{array}{l}\text { Deep ocean to } \\
\text { harbor } \\
\text { entrance }\end{array}$ & $0100 \mathrm{~m}^{1}$ & $\begin{array}{l}\text { WIS Phase I; } \\
\text { and/or NDBC buoy }\end{array}$ & $\begin{array}{l}\text { 2-D spectra@ } \\
\text { harbor entrance }\end{array}$ & $\begin{array}{l}\text { Directional } \\
\text { array outside } \\
\text { harbor }\end{array}$ \\
\hline $\begin{array}{l}\text { HARBD numerical } \\
\text { harbor osciliation } \\
\text { model }\end{array}$ & $\begin{array}{l}\text { Harbor and } \\
\text { vicinity }\end{array}$ & $010 \mathrm{~m}^{1}$ & $\begin{array}{l}\text { R/D model output; } \\
\text { and/or directional } \\
\text { array }\end{array}$ & $\begin{array}{l}\text { Amplification } \\
\text { spectra inside } \\
\text { harbor }\end{array}$ & $\begin{array}{l}\text { Nondirectional } \\
\text { gauges in } \\
\text { harbor }\end{array}$ \\
\hline $\begin{array}{l}\text { 3-D physical } \\
\text { harbor model }\end{array}$ & $\begin{array}{l}\text { Harbor and } \\
\text { vicinity }\end{array}$ & Continuous & $\begin{array}{l}\text { R/D model output; } \\
\text { and/or directional } \\
\text { array }\end{array}$ & $\begin{array}{l}\text { 2-D spectra } \\
\text { inside harbor }\end{array}$ & $\begin{array}{l}\text { Nondirectional } \\
\text { gauges in } \\
\text { harbor }\end{array}$ \\
\hline \begin{tabular}{l}
1 O $10 \mathrm{~m}$ is shorthand for “on the order of $10 \mathrm{~m} . "$ \\
\hline
\end{tabular}
\end{tabular}

the study, empirical relations between swell energy and seiche energy will be obtained from the wave measurements. This relationship will be utilized to verify similarity in the physical model and to develop the statistical predictions of harbor response.

The HARBD model assumes that all energy is either reflected or absorbed at boundaries, but no transmission occurs through boundaries. A method of representing the permeable walls will be described, but no tests of the accuracy of this "simulated permeability" have been conducted. Physical models, properly scaled and calibrated, will also be used to simulate the transmission of energy through and over the structure.

\section{Logistics}

The models described above require measurements of wave energy as a function of frequency (1-D spectrum) or frequency and direction (2-D spectrum). Two generic types of wave gauges, buoys and bottommounted pressure gauges, are generally utilized to obtain these data (Hemsley, McGehee, and Kucharski 1991). A surface following buoy was selected for the deep-ocean WIS calibration site, and bottom-mounted pressure gauges for the harbor network. Single pressure gauges are used to obtain 1-D, or nondirectional spectra, and 2-D spectra are obtained from an array of four sensors on a single frame.

Bottom-mounted instruments can be either self-contained or cable connected to shore. Armored cables provide power to the underwater sensor 
and carry the signal to electronic systems on shore, where they can be stored and/or telemetered (via radio or telephone) to a central collection computer. A real-time reporting, cable-connected network was selected for the harbor gauges to improve chances of data capture, and to provide HDOT with the potential for developing a wave monitoring system for use in harbor operations.

System acquisition and installation costs are affected by the length of the cable; therefore, it is desirable to minimize the distance from the shore electronics station to the sensor. Practical locations for the shore station must have protection from elements and tampering, and access to $110-\mathrm{V}$ electrical power and telephone lines. Locations were identified during previous site visits at the eastern corner of the harbor and the outer end of pier 2 (Figure 2). An upper limit on the cable length is approximately $2 \mathrm{~km}$ before expensive in-line amplifiers are required, so all sensor sites must be within $2 \mathrm{~km}$ of either shore station site.

While the underwater sensors are subject to electronic failure and water leakage problems, experience has shown ship activity to be the principal hazard. Activities around the harbor that threaten either the gauges or their cables are anchoring and dragging of barge tow bridles. For this reason, instruments and cable routes should avoid anchorages and the principal navigation channels - particularly near the entrance where tow bridles are adjusted.

Installation of the bottom-mounted sensors requires divers. As installation depths increase, significant time penalties on diver bottom time accumulate. Another depth limitation is the attenuated frequency response of pressure sensors with increasing depth. Both factors dictated a maximum sensor depth of about $20 \mathrm{~m}$. For additional information on gauges and gauge site selection, see Hemsley, McGehee, and Kucharski (1991).

A major factor influencing the site selection process is the areas of interest from the perspective of the port activities. Current operations are principally in the eastern corner and northeastern side of the harbor. Future expansion options (2010 Master Plan, HDOT (1989)) are the southern side, west of Pier 2, and the northwestern side of the harbor. Proper validation of the models for these areas in their current configuration is important for establishing confidence in predictions for new configurations. 


\section{HARBD Numerical Model}

\section{HARBD Model Description}

The sometimes complex spatial structure of harbor seiches, with minima and maxima of sea surface elevation (i.e, nodes and antinodes), is determined by the harbor geometry and bathymetry. The spatial structure of the resonant modes, within the frequency range of likely seiches at Kahului Harbor $(0.001-0.01 \mathrm{~Hz})$ was obtained numerically using the Corps HARBD model (Chen 1986, Chen and Houston 1987). The numerical model is the solution of a boundary value problem for linear gravity waves in a domain of arbitrary shape and variable depth (Chen and Mei 1974, Houston 1981). The model domain is divided into a variable-depth near field and a constant-depth far field, separated by an artificial semicircular boundary where solutions are matched. The solution in the near field is found using finite element techniques and the far-field solution is analytic.

Dissipative effects of bottom friction and boundary absorption can be included in the model, and the sensitivity of the modal spatial structure to these sources of energy losses has been investigated. Bottom friction is assumed to be linearly proportional to the horizontal velocity and is prescribed in terms of a spatially variable bottom friction coefficient $\beta$ where the inviscid solution is obtained using $\beta=0$ everywhere. Side-wall boundary absorption is prescribed in terms of a reflection coefficient $R$, where $R=1$ implies perfect reflection. HARBD does not allow wave transmission at boundaries, so if waves impinging on the breakwaters are only partially reflected, the remainder is absorbed.

Undesirable wave reflection, refraction, and scattering occur at the depth discontinuity along the semicircular boundary between the variabledepth near field and the constant-depth far field. Effects of these depth discontinuities are reduced by placing the semicircular boundary where the actual bathymetry is relatively smooth and planar and selecting a constant far-field depth matching the measured bathymetry over a large portion of the boundary (Okihiro, Guza, and Seymour, in preparation). Nonzero bottom friction can also be specified near the boundary between 
the coast and the semicircular boundary to further reduce the bogus effects of these depth discontinuities.

\section{Finite Element Grids}

The bathymetric grid used in the near-field model solution was constructed from bathymetric surveys obtained from the Corps, HDOT, and the National Ocean Service/National Oceanic and Atmospheric Administration. Very little data was available for the shallow areas (i.e., $<2 \mathrm{~m}$ ) both inside and outside the harbor. The sensitivity of the model results to the specification of depths in these shallow areas and the magnitude of the discrepancies between the model results and observation can be used to determine whether additional bathymetry data should be incorporated into the model grids for future work.

Mean sea level was used in all the model tests. The constant depth in the far field was chosen to be $14 \mathrm{~m}$. The triangular elements had dimensions of 15-30 m (less than 1/6 of the local wavelength). Model tests were run on the Office of Naval Research Cray Y-MP and the Center for Coastal Studies (at SIO) Sun 670MP. 


\section{HARBD Model Tests and Results}

\section{HARBD Model Tests}

The HARBD model tests are summarized in Table 2. Owing to limitations on available computer resources, model results were obtained for a single incident wave direction, approximately $18 \mathrm{deg}$ east of north (Figure 2) and for frequencies less than $0.012 \mathrm{~Hz}$. Limited model tests with varying incident wave directions showed that while the magnitude of the resonant peaks may vary somewhat as a function of incident wave direction, the resonant frequencies are not highly sensitive to direction. Based on previous work with a similar sized harbor (Okihiro, Guza, and Seymour, in preparation) most of the seiche energy is expected to be at frequencies less than $-0.012 \mathrm{~Hz}$.

\begin{tabular}{|l|l|l|l|l|l|l|l|}
\hline \multicolumn{7}{|l|}{$\begin{array}{l}\text { Table 2 } \\
\text { HARBD Numerical Model Tests }\end{array}$} \\
\hline Test & $\begin{array}{l}\text { Offshore } \\
\text { Grid } \\
\text { Radius, km }\end{array}$ & $\begin{array}{l}\text { Cray CPU/ } \\
\text { frequency, } \\
\text { seconds }\end{array}$ & No. Nodes & $\begin{array}{l}\text { No. } \\
\text { Elements }\end{array}$ & $\begin{array}{l}\text { Harbor } \\
\text { Goometry }\end{array}$ & $\begin{array}{l}\text { Boundary } \\
\text { Reflectlon } \\
\text { R }\end{array}$ & $\begin{array}{l}\text { Bottom } \\
\text { Frlctlon } \\
\beta\end{array}$ \\
\hline 1 & 2.0 & 600 & 18,483 & 36,106 & Prototype & 1.0 & 0.0 \\
\hline 2 & 0.5 & 37 & 3,679 & 6,911 & Prototype & 1.0 & 0.0 \\
\hline 3 & 0.5 & 37 & 3,679 & 6,911 & $\begin{array}{l}\text { Constant } \\
\text { depth }\end{array}$ & 1.0 & 0.0 \\
\hline 4 & 0.5 & 37 & 3,679 & 6,911 & Prototype & 1.0 & 0.001 \\
\hline 5 & 0.5 & 37 & 3,679 & 6,911 & Prototype & 0.95 & 0.0 \\
\hline 6 & 0.5 & 37 & 3,727 & 7,068 & $\begin{array}{l}\text { No } \\
\text { breakwater }\end{array}$ & 1.0 & 0.0 \\
\hline
\end{tabular}




\section{Inviscid Tests}

The first set of model tests (Tests 1 and 2, Table 2) neglected bottom friction (i.e., $b=0$ ) and assumed complete reflection $(R=1)$ along the coastline and harbor perimeter. The Test 1 grid $(36,106$ elements and 18,483 nodes) included a large offshore area (dashed line in Figure 2) and required $\sim 10 \mathrm{~min}$ of central processing unit (cpu) on the Cray Y-MP for a single frequency and direction. The Test 2 grid $(6,911$ elements and 3,679 nodes) included a much smaller offshore area (dotted line in Figure 2) and required only $-37 \mathrm{~s}$ of cpu time for each test.

Comparisons between the results from the two different size grids (i.e., Tests 1 and 2) showed only small differences between the predicted resonant frequencies and spatial distribution of energy at those frequencies. Although the resonant frequencies predicted by the big (Test 1) and small (Test 2) grids were similar, there were significant differences between the magnitudes of the resonant peaks. To significantly reduce the cpu time required, and because small grid results are adequate for determining sensor placement, subsequent seiche tests for this study primarily used the small grid. Future work comparing the magnitude of predicted and observed resonance should use a grid large enough to reduce model artifacts.

Sea surface elevation amplification (with respect to an incident wave of amplitude 1.0 at the near-field mode boundary) spectra between 0.0005 and $0.012 \mathrm{~Hz}$ from 15 locations (solid symbols in Figure 3) within the harbor are shown in Figure 5. There are numerous amplification peaks in this frequency band with varying magnitudes depending on the location in the harbor.

Examples of the spatial structure at several resonant frequencies are shown in Figures 6-9. At the grave mode frequency $(-0.001 \mathrm{~Hz}$, Figure 6), relatively uniform amplifications in the harbor interior decrease towards the harbor mouth. This very low frequency mode is relatively broad with significant amplifications over a range of frequencies (Figure 5). The spatial structure of the narrower peak in the amplification spectrum at $-0.003 \mathrm{~Hz}$ (Figure 5) is shown in Figure 7. This seiche rocks back and forth between the east and west sides of the harbor with a nodal line (zero crossing) in the north-south direction in the middle of the harbor.

At higher resonant frequencies the spatial patterns of wave amplification are more complex with multiple nodes and antinodes. Above $0.006 \mathrm{~Hz}$ the amplification spectrum is dominated by modes with edgewave-like spatial patterns (Figures 8-9). These modes are characterized by nodes and antinodes along the south side of the harbor with the largest amplifications along the shoreline and decreasing amplifications towards the deeper water in the center of the harbor. 


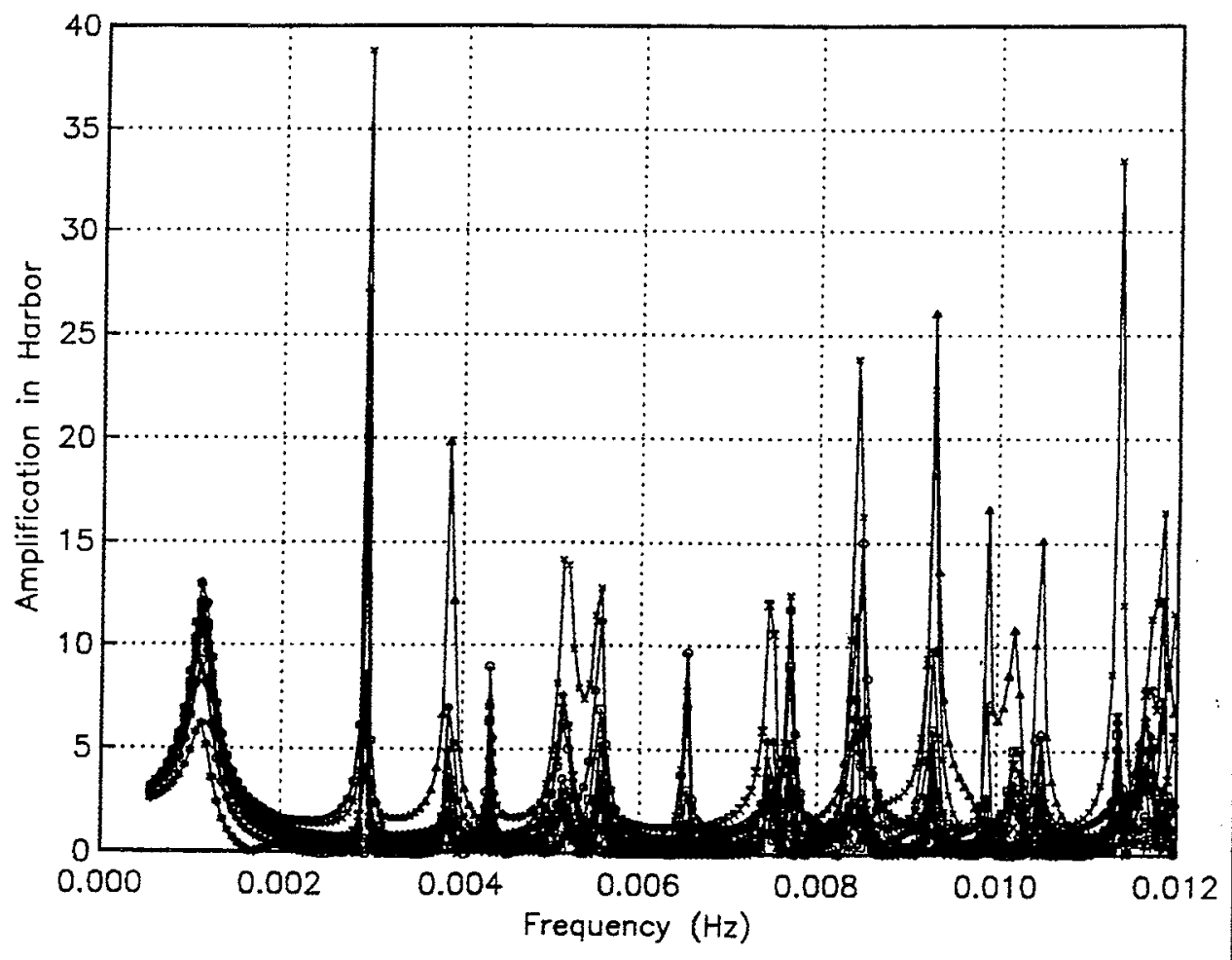

Figure 5. HARBD model-predicted sea surface elevation amplification spectra with respect to incident waves of amplitude 1.0 at the near-field boundary (dotted line in Figure 2) for inviscid waves (Test 2) at various locations in the harbor (shown by solid symbols in Figure 3 )

\section{Constant Depth Harbor}

Model tests with a constant depth harbor were run to determine whether the 'edge' modes in Figures 8 and 9 were due to the overall shape of the harbor or a result of refractive trapping of energy by the shallow depths along the west and south sides of the harbor (i.e., edge waves). In Test 3 the offshore depths were not altered but the harbor depth was uniformly $13 \mathrm{~m}$.

Amplification spectra in this case (Figure 10) have many fewer resonant modes than with the field bathymetry (compare Figures 5 and 10). None of the resonant modes for this constant-depth harbor have the 'edge' spatial patterns predicted with the real bathymetry. These results indicate 


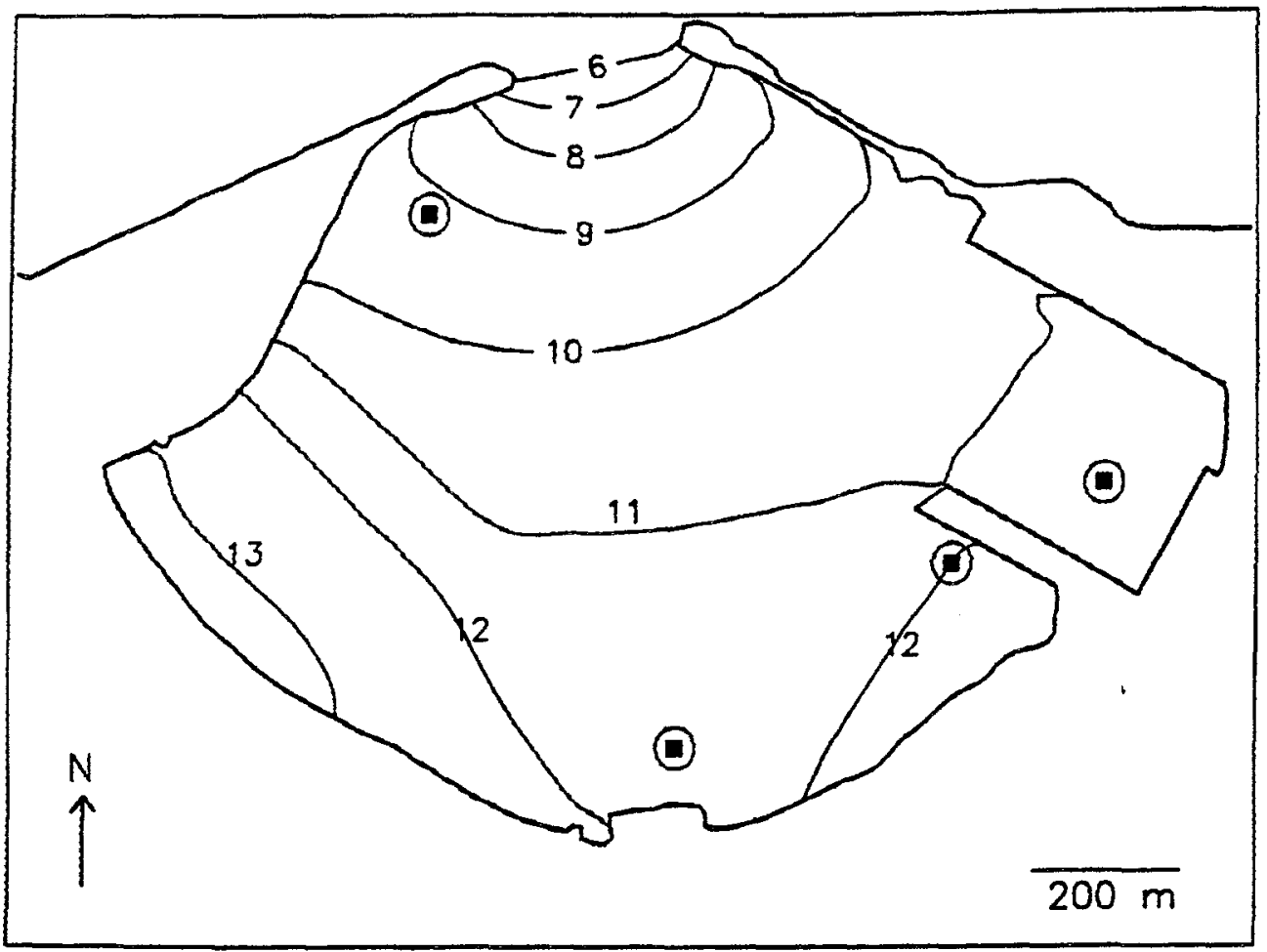

Figure 6. Contours of model-predicted wave amplification with respect to unit wave amplitude at the near-field boundary (dotted line in Figure 2) for inviscid waves at $f=0.0011 \mathrm{~Hz}$ (Test 2). Dashed lines are amplification of -0 . Circles indicate the selected harbor sensor sites

that the predicated 'edge' modes are predominantly a function of the shallow bathymetry and not the shape of the harbor. If these 'edge' modes are energetic in the field observations, it is likely they could be suppressed by dredging.

\section{Bottom Friction}

Sensitivity of the resonant frequencies and spatial patterns of amplification to bottom friction was tested using a constant bottom friction coefficient $b=0.001$ (Test 4 ). The results showed only slight shifts in the resonant frequencies with little change in the spatial patterns of amplification compared to the inviscid results (Test 2). However, with the exception of the grave mode $(-0.001 \mathrm{~Hz})$ which showed only a slight reduction in amplification, magnitudes of the resonant peaks were drastically reduced by bottom friction. 


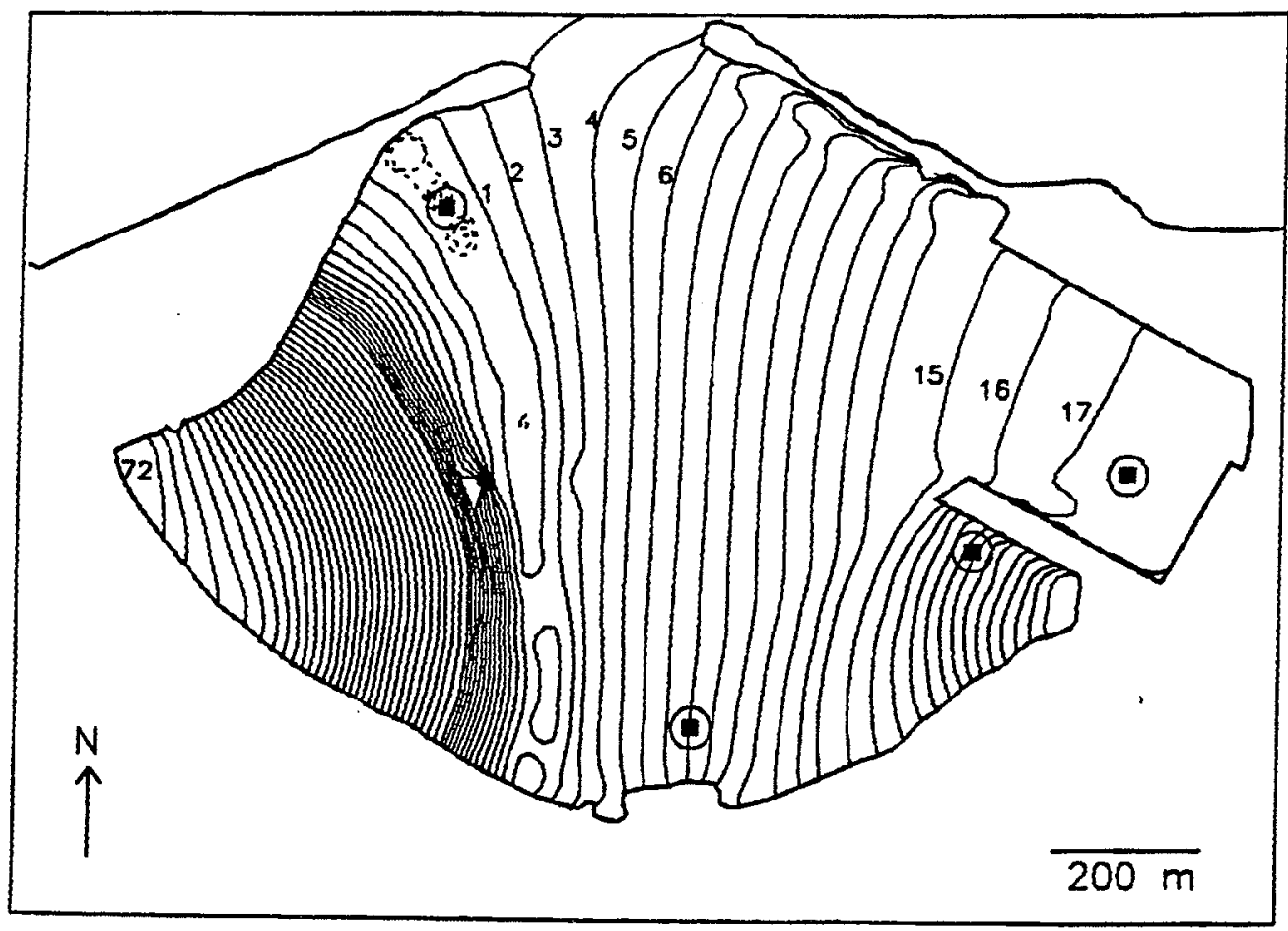

Figure 7. Contours of wave amplification for $\mathrm{f}=0.0029 \mathrm{~Hz}$ (see caption for Figure 6)

\section{Boundary Reflection}

Sensitivity of the harbor amplifications to boundary absorption was also tested (Test 5). The results showed that a small change in boundary reflectivity $(\mathrm{R}=0.95)$ results in significant decreases in the amplifications but has little effect on the frequencies and spatial structure of the resonant modes.

\section{Rubble-Mound Breakwaters}

The purpose of the last test (Test 6) was to determine the sensitivity of the seiche modes to possible transmission of waves over the rubblemound breakwaters. Replacing all or part of the breakwater with a submerged breakwater is one way to simulate wave transmission through a boundary in HARBD (Houston 1976). The end portions of the breakwater (an -200-m-long section of the west breakwater and an $\sim 400-\mathrm{m}-\mathrm{long}$ section of the east breakwater) are relatively thin, rubble-mound sections that may be susceptible to transmission. These portions were removed in the model test grid by replacing the zero-depth breakwater surface area with 2-m water depths. Although the reflecting elements of the breakwater 


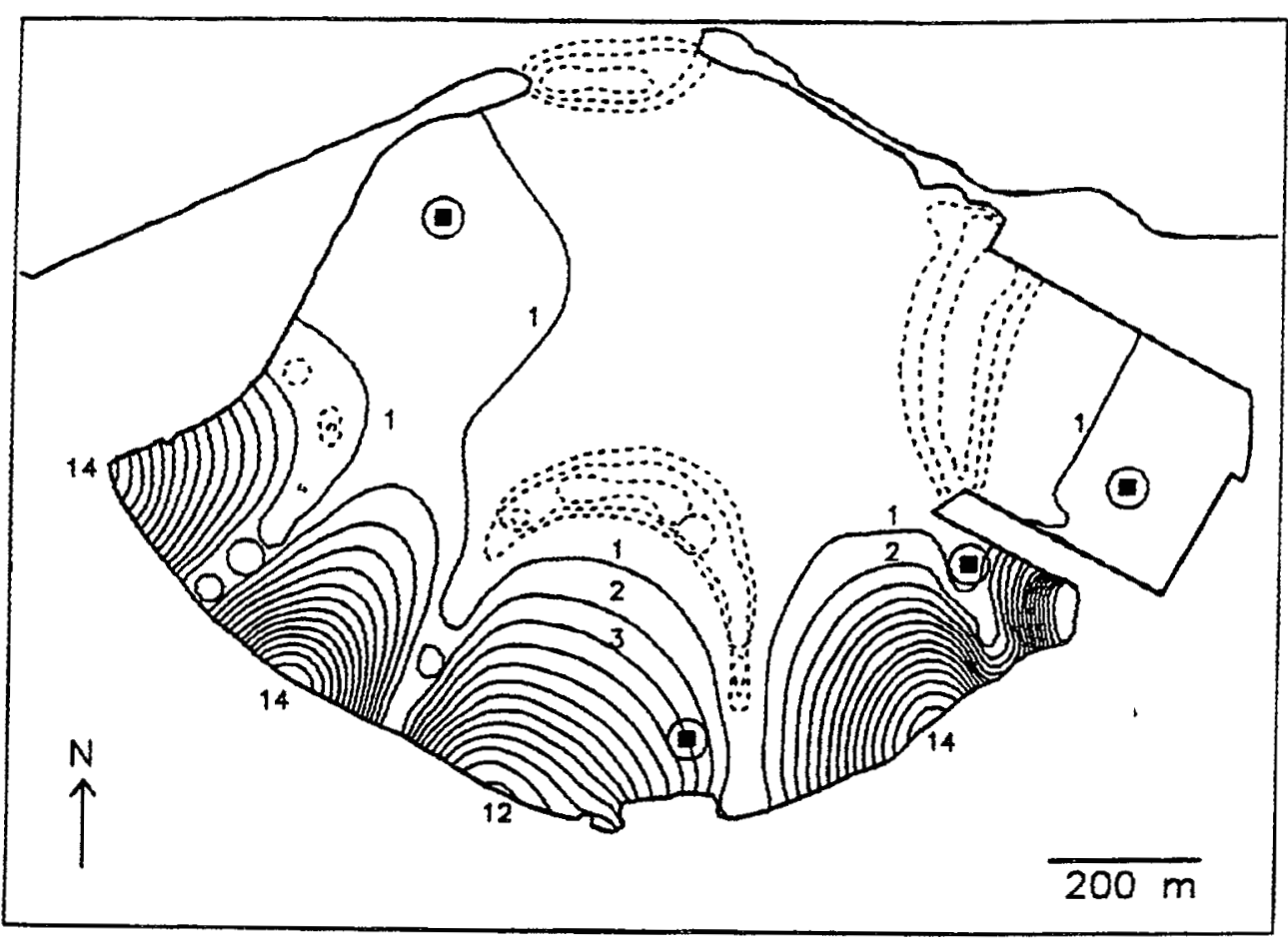

Figure 8. Contours of wave amplification for $\mathrm{f}=0.0065 \mathrm{~Hz}$ (see caption for Figure 6)

boundary were no longer present in the model, the effect of the breakwaters was not completely removed because of the shallow depths which remained at the breakwater location.

Resonant frequencies and spatial patterns of amplification for this harbor with shallow shoals instead of breakwaters were similar to the results obtained for the inviscid harbor in Test 2. There was a slight shift in the grave mode peak frequency $(-0013 \mathrm{~Hz})$ for this harbor geometry compared to the harbor with impermeable breakwaters (i.e. Test 2), and magnitudes of amplification were also different. Some modes in the harbor without breakwaters are more resonant (i.e., bigger amplifications) and some are less resonant than the harbor with breakwaters). 


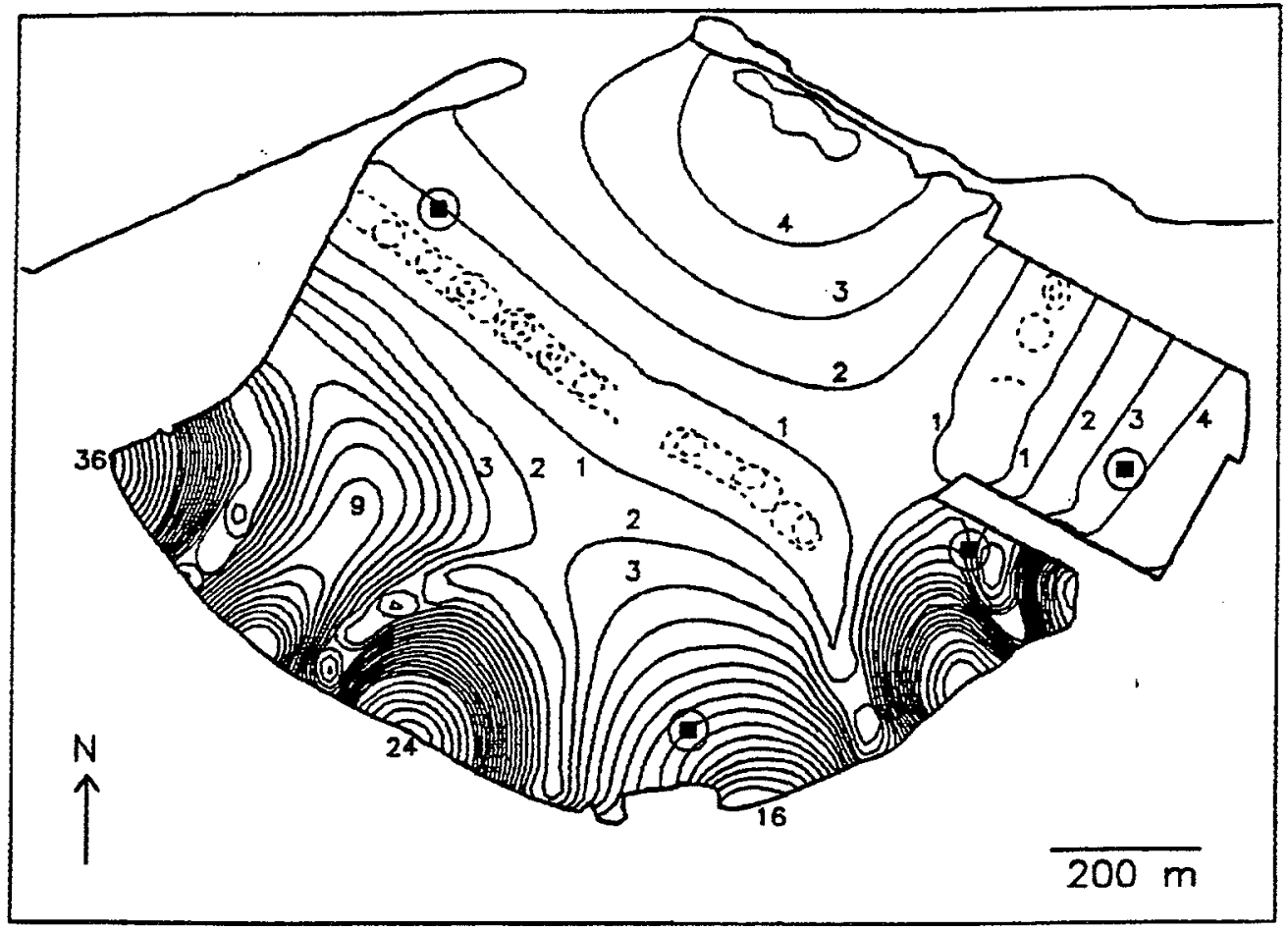

Figure 9. Contours of wave amplification for $\mathrm{f}=0.0077 \mathrm{~Hz}$ (see caption for Figure 6) 


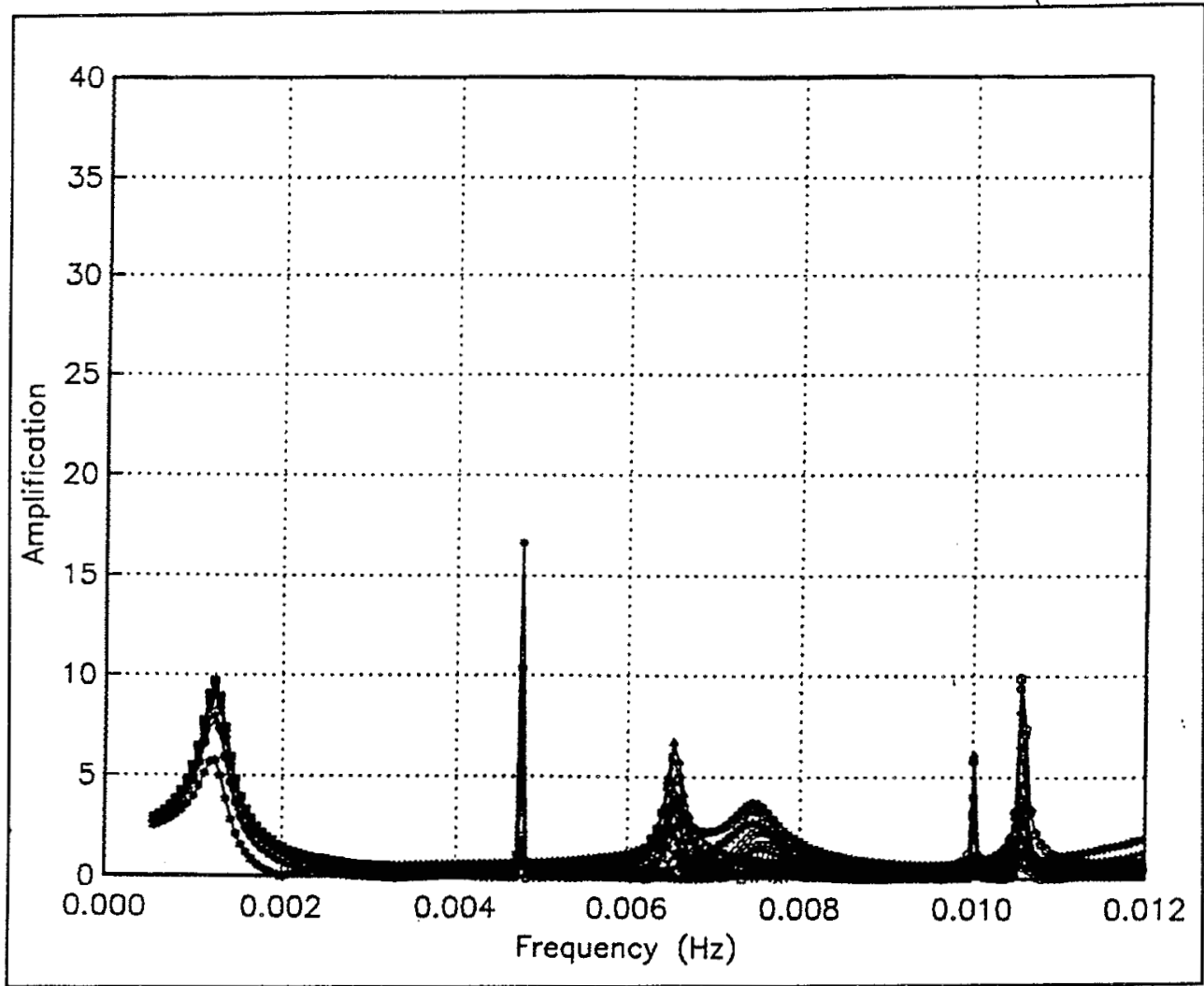

Figure 10. Model-predicted amplification spectra (see caption for Figure 5) for a constant depth (13-m) harbor (Test 3) at various locations in the harbor (shown by solid symbols in Figure 3 ) 


\section{Site Selection}

\section{Harbor Sensors}

Sites chosen for the four harbor sensors are shown by lettered circles in Figure 3 and circles in Figures 5-8. Amplification spectra from HARBD Test 2 for these four sites are shown in Figure 11. Sensor A will be between three main piers where most of the present harbor operations are located and sensor B will be positioned in the vicinity of a proposed passenger ship and ferry terminal (HDOT 1989). Sites A and B are expected to be dominated by the 'normal' harbor seiche modes (Figures 6 and 7).

Sensors $C$ and $D$, located along the shallow southeast perimeter of the harbor, will be used to determine the significance of the predicted 'edge' modes (e.g., Figures 8 and 9). Future modifications to the harbor are also being proposed for the area in the vicinity of these sensors, adding to the importance of resolving these potentially energetic 'edge' modes. For example, if a small area around site $\mathrm{D}$ were dredged to utilize the existing pier, 'edge' modes along the south boundary could be a very serious problem.

Time series of 2.3-hr duration will be collected at harbor sensors A, B, $C$, and D, with a sample rate of $1.0 \mathrm{~Hz}(2.0 \mathrm{~Hz}$ for site $\mathrm{D})$, which will allow for the resolution of sea, swell, and infragravity waves at these sites.

\section{Offshore Array Site}

The site for the offshore slope array was selected to measure both energy levels of the infragravity frequency motions outside the harbor and incident sea and swell representative of the area. The selected location was highly constrained by logistical considerations. Shipping lanes must be avoided for obvious reasons and sites deeper than $\sim 18 \mathrm{~m}$ were not considered both because of the limited bottom time for scuba divers during installation and the attenuation of high-frequency seas at the seafloor.

Cable lengths also limited the potential array sites. 


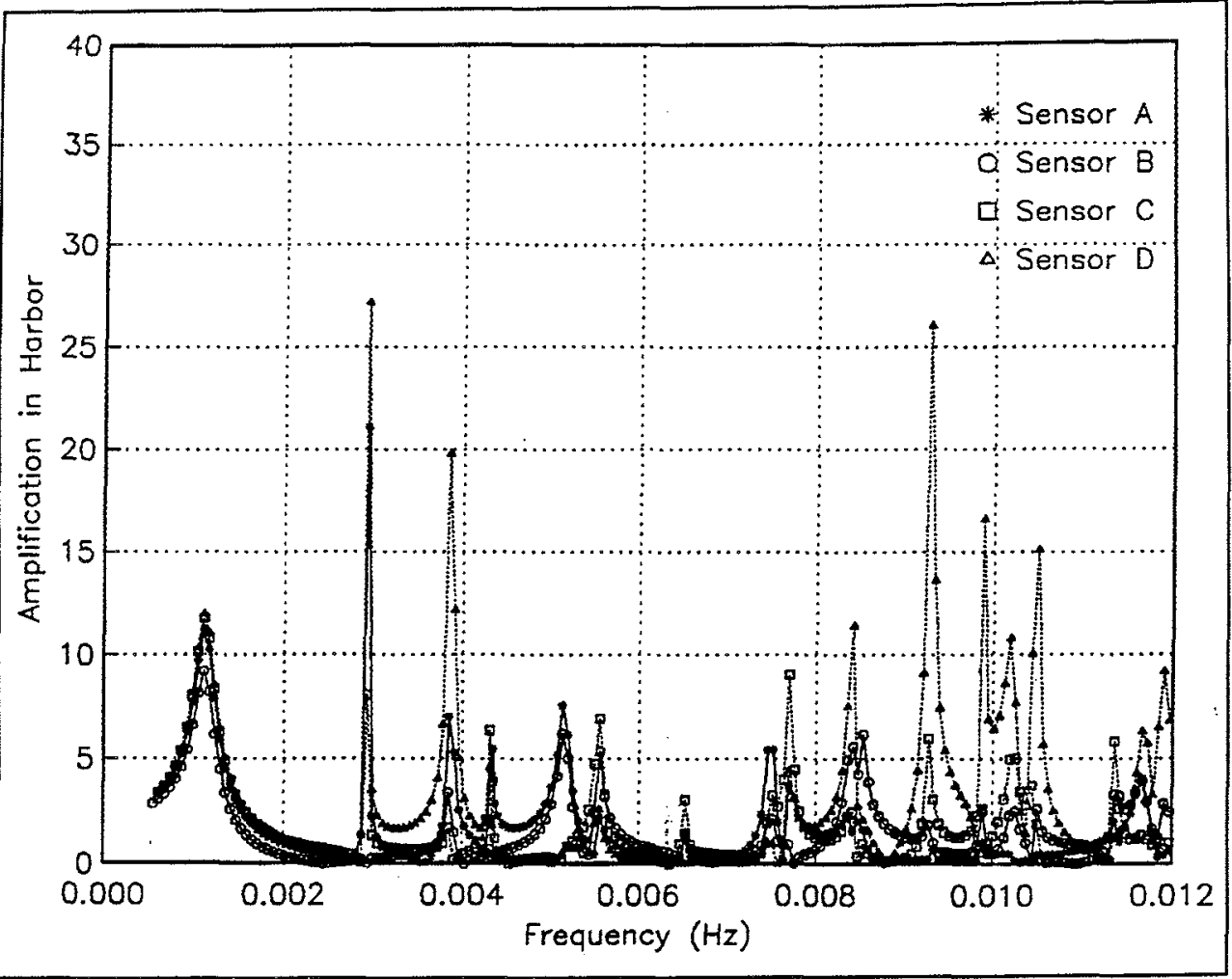

Figure 11. Amplification spectra (see caption for Figure 5) for inviscid waves (Test 2) at the selected harbor sensors (shown by lettered circles in Figure 3)

A refraction-diffraction numerical model (O'Reilly and Guza 1993) was used to simulate the transformation of sea and swell waves from deep water to offshore of the harbor. Examples of the swell (peak period =17 s) height (normalized by the deepwater height $H_{O}$ offshore of the harbor) for two incident wave directions are shown in Figure 12. Model results indicate that the offshore bathymetry at this site focuses the incoming waves resulting in convergence zones of high energy at certain locations which depend on the incident wave direction. Wave energy measured in these convergent zones will be site-specific and only qualitatively representative of the wave conditions over a larger area. None of the potential sites considered was out of these convergence zones for all probable incident wave directions.

The site selected for the slope array is shown in Figures 2 and 12. At this location the slope array will at least measure the sea and swell conditions that are impinging directly on the harbor. Results from HARBD using the large offshore grid (Test 1) also indicate that this slope array site is not located near nodes of the resonant harbor modes. Time series of 2.3-hr duration sampled at $1.0 \mathrm{~Hz}$ will be collected at each of the four pressure gauges in the slope array. 


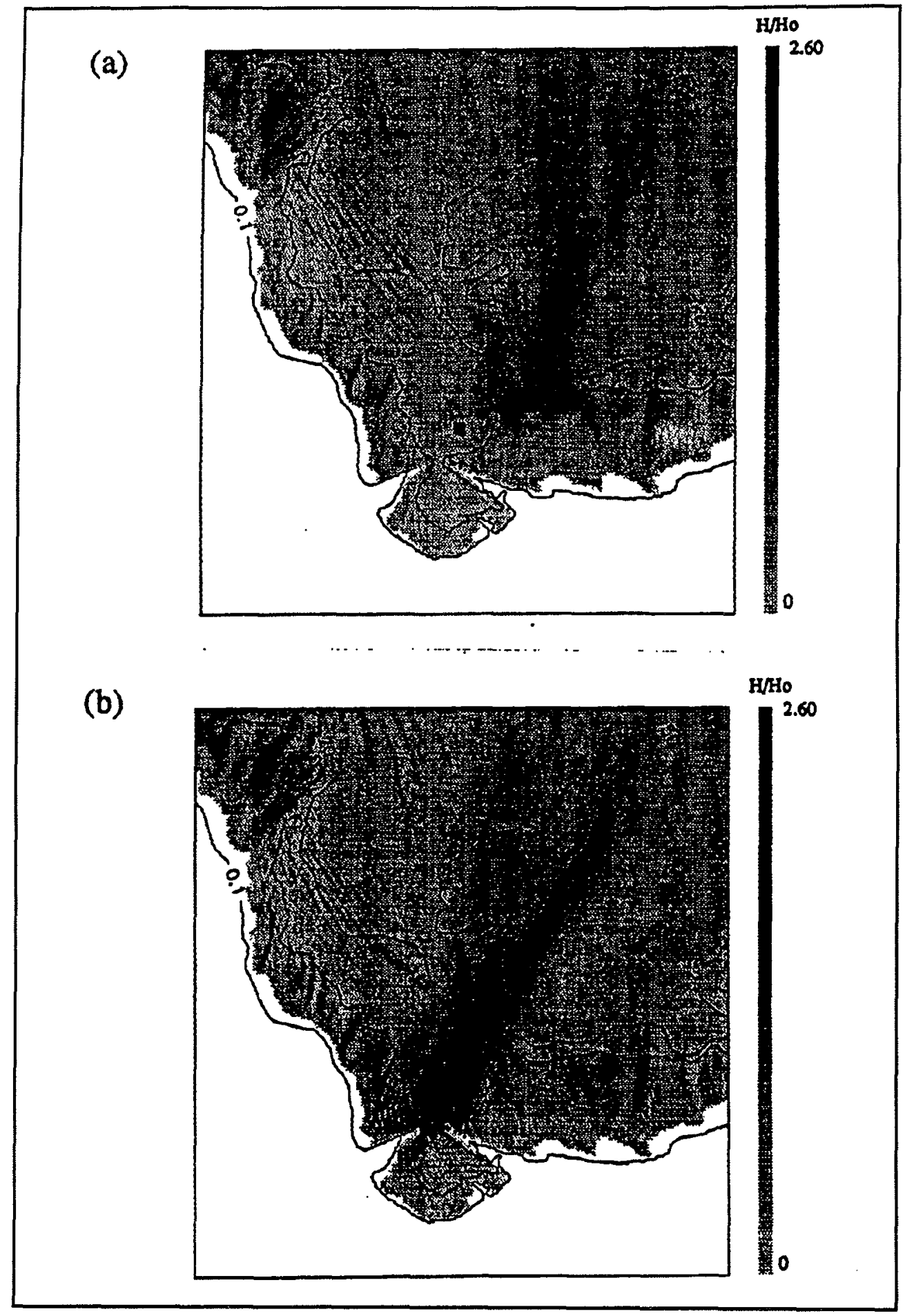

Figure 12. Refraction-diffraction model predicted swell (peak period $=17 \mathrm{~s}$ ) heights $H$ (normalized by the deepwater wave height $H_{O}$, scale is on the right-hand side) offshore of Kahului Harbor for incident waves from the north $\left(\Theta=355^{\circ}\right.$, Figure 12a) and northeast $\left(\Theta=15^{\circ}\right.$, Figure 12b) directions. The square symbol is the site selected for the array. Depth contours shown are in meters 


\section{Optional Autonomous Sensor Site}

An optional fifth nondirectional autonomous gauge is available for the Kahului study. The gauge is an internal recording, battery-operated gauge that could be placed without regard to cable restrictions. It will operate approximately 6 months, depending upon the sampling scheme. Four possible regions were considered for this gauge:

a. Inside the harbor, to better define harbor oscillations and provide additional calibration for the harbor models. The southwest corner is the most likely site within the harbor.

$b$. North of the harbor, to better define the incident wave field and provide additional calibration for the wave transformation model. A site on the western side of the entrance channel, to better define the shadowing effects of the reef on the eastern side, is the most likely site.

c. East of the harbor, to better define the incident waves for potential reclamation on the shallow region seaward of pier 1 . Data from this site would improve selection of design conditions for revetments.

$d$. Inside the western breakwater, to better define the transmission characteristics of this structure. There is no reliable way, using nondirectional gauges in the harbor, to separate energy coming through the entrance from energy coming through/over the breakwater. Accurate representation of the permeability of these structures may be possible in the physical models, with appropriate calibration. A gauge inside the breakwater, located above the normal high-water line, will record the effects of large waves overtopping the structure.

The four alternatives are listed in order of decreasing confidence in the ability to effectively model the processes being measured, and thus make direct application of the measurements. This does not imply they are in decreasing order of value. A fifth gauge in the harbor provides incremental information over four gauges, but given the complex bathymetry offshore, the R/D wave transformation model would benefit even more from a second calibration point. However, a directional gauge would be more useful for this purpose than a nondirectional gauge. Design wave information is needed for future revetment design, but unless an extreme event occurs while the gauge is in place, it will be difficult to predict conditions on the reef flat from statistically derived extreme conditions offshore. Finally, the need to accurately model the processes in the harbor, which include wave overtopping during high wave conditions, is countered by uncertainty in the ability to reduce the complex signal from a gauge in this environment to a usable calibration product for any model. 
Selection of the best location will not be made at this time. Analysis of the data from the existing gauges and experience with the models will provide the best guidance on the need for additional measurements. If indicated, the optimal site for an additional gauge will be decided later in the study.

\section{Summary}

The immediate purpose of the sensor placement study was to design a wave measurement program which would aid in understanding forcing and damping of seiche in the existing harbor, and also to empirically determine certain harbor-specific modeling parameters vital for the study of future modifications. Limitations on resources and logistics constrained the experiment design. The resources allocated to the wave measurement study include a directional slope array to measure the incident wave conditions offshore of the harbor and four pressure sensors to measure the harbor seiche. An additional autonomous (self-contained) pressure sensor is available and possible locations for this gauge were discussed. The response of Kahului Harbor to infragravity frequency $(0.001-0.01 \mathrm{~Hz})$ waves was numerically modelled with the HARBD model.

Results of the numerical model tests show that Kahului Harbor is characterized by numerous resonant modes in the frequency band from 0.001 to $0.012 \mathrm{~Hz}$. These modes can be qualitatively separated into what we refer to as 'normal' seiche modes and 'edge' modes. The 'normal' modes (e.g., Figures 6 and 7) are a function primarily of the harbor shape and average depth with few nodes (zero amplitudes) within the harbor. In contrast, the 'edge' modes (e.g., Figures 8 and 9) are a function primarily of the shallow sloping south harbor boundary and are manifested by nodes and antinodes aligned along this boundary and high amplifications along the harbor shoreline. The spatial structure and frequencies of seiche were not sensitive to reasonable variations in bottom friction, boundary reflection, and breakwater transmissivity as prescribed in the HARBD numerical model.

An R/D wave transformation numerical model was used to estimate offshore sea and swell conditions. Based on the results of the (uncalibrated) models, sensor placements were selected which are best suited to characterize the frequencies, spatial structure, and magnitude of the resonant modes and which quantify the most important modeling unknowns: (a) the energy level of low-frequency motions outside the harbor and their various driving forces (e.g., energy of sea and swell) and (b) the damping (inside the harbor and breakwaters) which can dramatically reduce the amplitude of resonant seiches.

Recommendations from this report were followed in deployment of the Kahului Harbor gauge network in October of 1993. The network was installed and is operated by the Ocean Engineering Research Group at the SIO. 


\section{References}

Basco, D. R., and McGehee, D. D. (1990). "A methodology to select nearshore wave gauge sites: The Virginia wave gauge study," Report No. 90-1, Coastal Engineering Insitute, Old Dominion University, Norfolk, VA.

Chen, H. S. (1986). "Effects of bottom friction and boundary absorption on water wave scattering," Applied Ocean Research 8(2), 99-104.

Chen, H. S., and Houston, J. R. (1987). "Calculation of water oscillation in coastal harbors; HARBS and HARBD user's manual," Instruction Report CERC-87-2, U.S. Army Engineer Waterways Experiment Station, Vicksburg, MS.

Chen, H. S., and Mei, C. C. (1974). "Oscillations and wave forces in an offshore harbor," Ralph M. Parsons Lab. Rep. 190, Mass. Inst. of Technol., Cambridge, MA.

Corson, W. D., Abel, C. E., Brooks, R. M., Farrar, P. D., Groves, B. J., Jensen, R. E., Payne, J. B., Ragsdale, D. S., and Tracy, B. A. (1986). "Pacific coast hindcast deepwater wave information," WIS Report 14, U.S. Army Engineer Waterways Experiment Station, Vicksburg, MS.

Hawaii Department of Tranportation. (1989). "2010 Master Plan for Kahului Harbor, Maui," State of Hawaii Department of Transportation, Harbors Division.

Hemsley, J. M., McGehee, D. D., and Kucharski, W. M. (1991). "Nearshore oceanographic measurements: Hints on how to make them," Journal of Coastal Research 7(2), 301-15.

Houston, J. R. (1976). "Long Beach Harbor numerical analysis of harbor oscillations," Miscellaneous Paper H-76-20, U.S. Army Engineer Waterways Experiment Station, Vicksburg, MS.

(1981). "Combined refreaction and diffraction of short waves using the finite element method," Applied Ocean Research 3(4), 16370. 
Okihiro, J., Guza, R. T., and Seymour, R. J. "Excitation of seiche observed in a small harbor," in preparation, Journal of Geophysical

Research.

O'Reilly, W. C., and Guza, R. T. (1993). "A comparison of two spectral wave models in the Southern California Byte," Coastal Engineering 9, 263-82. 


\begin{tabular}{|c|c|c|c|c|c|}
\hline \multicolumn{4}{|c|}{ REPORT DOCUMENTATION PAGE } & \multicolumn{2}{|r|}{$\begin{array}{l}\text { Form Approved } \\
\text { OMB No. 0704-0188 }\end{array}$} \\
\hline \multicolumn{6}{|c|}{ 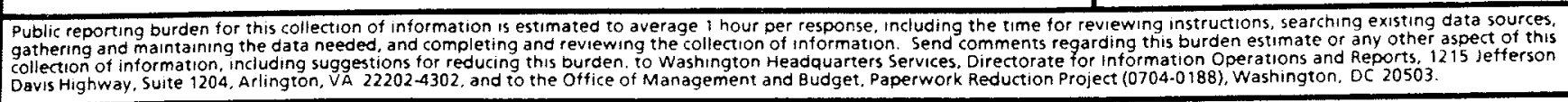 } \\
\hline \multicolumn{2}{|c|}{ 1. AGENCY USE ONLY (Leave blank) } & $\begin{array}{r}\text { 2. REPORT DATE } \\
\text { May } 1994\end{array}$ & \multicolumn{3}{|c|}{$\begin{array}{l}\text { 3. REPORT TYPE AND DATES COVERED } \\
\text { Final report }\end{array}$} \\
\hline \multicolumn{4}{|c|}{$\begin{array}{l}\text { 4. TITLE AND SUBTITLE } \\
\text { Selecting Wave Gauge Sites for Monitoring Harbor Oscillations: A } \\
\text { Case Study for Kahului Harbor, Hawaii }\end{array}$} & \multirow{2}{*}{\multicolumn{2}{|c|}{ 5. FUNDING NUMBERS }} \\
\hline \multicolumn{4}{|c|}{$\begin{array}{l}\text { 6. AUTHOR(S) } \\
\text { Michele Okihiro, R. T. Guza, W. C. O'Reilly, David D. McGehee }\end{array}$} & & \\
\hline \multicolumn{4}{|c|}{$\begin{array}{l}\text { 7. PERFORMING ORGANIZATION NAME(S) AND ADDRESS(ES) } \\
\text { Scripps Institution of Oceanography, } \\
\text { University of California, San Diego, La Jolla, CA } \\
\text { U.S. Army Engineer Waterways Experiment Station } \\
\text { 3909 Halls Ferry Road, Vicksburg, MS 39180-6199 }\end{array}$} & \multicolumn{2}{|c|}{$\begin{array}{l}\text { 8. PERFORMING ORGANIZATION } \\
\text { REPORT NUMBER } \\
\text { Miscellaneous Paper } \\
\text { CERC-94-10 }\end{array}$} \\
\hline \multicolumn{4}{|c|}{$\begin{array}{l}\text { 9. SPONSORING /MONITORING AGENCY NAME(S) AND ADDRESS(ES) } \\
\text { U.S. Army Corps of Engineers } \\
\text { Washington, DC 20314-1000; } \\
\text { State of Hawaii } \\
\text { Hawaii Department of Transportation, Harbors Division } \\
\text { 79 S. Nimitz Hwy, Honolulu, HI } 96813\end{array}$} & \multicolumn{2}{|c|}{$\begin{array}{l}\text { 10. SPONSORING/MONITORING } \\
\text { AGENCY REPORT NUMBER }\end{array}$} \\
\hline \multicolumn{6}{|l|}{ 11. SUPPLEMENTARY NOTES } \\
\hline \multicolumn{6}{|c|}{ Available from National Technical Information Service, 5285 Port Royal Road, Springfield, VA 22161.} \\
\hline \multicolumn{4}{|c|}{$\begin{array}{l}\text { 12a. DISTRIBUTION / AVAILABILITY STATEMENT } \\
\text { Approved for public release; distribution is unlimited. }\end{array}$} & \multicolumn{2}{|c|}{ 12b. DISTRIBUTION CODE } \\
\hline \multirow{2}{*}{\multicolumn{6}{|c|}{$\begin{array}{l}\text { 13. ABSTRACT (Maximum 200words) } \\
\text { The U.S. Army Corps of Engineers Field Wave Gaging Program (FWGP) operates a nationwide network } \\
\text { of wave gauges and serves as the Corps' central access point for all U.S. wave data. This is the third in a se- } \\
\text { ries of FWGP reports describing, through case studies, the process of selecting sites for wave gauges. } \\
\text { This report illustrates the use of two different models to optimize gauge sites in a local gauge network for } \\
\text { a harbor oscillation study. The harbor that was studied is Kahului Harbor, Hawaii. Results of the numerical } \\
\text { model tests show that Kahului Harbor is characterized by numerous resonant modes in the frequency band } \\
\text { from } 0.001 \text { to } 0.012 \mathrm{~Hz} \text {. Recommendations from this report were followed in deployment of the Kahului Har- } \\
\text { bor gauge network in October of } 1993 \text {. The network was installed and is operated by the Ocean Engineering } \\
\text { Research Group at the Scripps Institution of Oceanography. }\end{array}$}} \\
\hline & & & & & \\
\hline \multicolumn{4}{|l|}{ 14. SUBJECT TERMS } & & $\begin{array}{l}\text { 15. NUMBER OF PAGES } \\
33\end{array}$ \\
\hline $\begin{array}{l}\text { HARBD } \\
\text { Harbor oscillation }\end{array}$ & Wav & $\begin{array}{l}\text { gauges } \\
\text { transformation models }\end{array}$ & & & 16. PRICE CODE \\
\hline $\begin{array}{l}\text { 17. SECURITY CLASSIFICATION } \\
\text { OF REPORT } \\
\text { UNCLASSIFIED }\end{array}$ & US & $\begin{array}{l}\text { ECURITY CLASSIFICATION } \\
\text { F THIS PAGE } \\
\text { CLASSIFIED }\end{array}$ & $\begin{array}{l}\text { 19. SECURIT } \\
\text { OF ABST }\end{array}$ & CATION & 20. LIMITATION OF ABSTRACT \\
\hline
\end{tabular}

